\title{
Chitra Banerjee Divakaruni's Literary Works: A Review
}

\author{
*V.Gunasundari M.A. \\ Research Associate \\ SSL \\ VIT University \\ Vellore - 632014 \\ **Dr.N.S.Vishnu priya M.A., M.Phil., Ph.D. \\ Assistant Professor (Senior) \\ SSL \\ VIT University \\ Vellore - 632014
}

DOI: $10.7176 / J L L L / 54-01$

Publication date:March $31^{\text {st }} 2019$

Chitra Banerjee Divakaruni is a contemporary Indian-American writer known for her brilliant exploration of South Asian immigrant experiences. She accomplished her literary career in three genres such as poetry, novel and short stories. The present review article attempts to discuss Divakaruni's themes, techniques incorporated in her literary works with the help of research carried out on Divakaruni's fiction by various researchers.

Chitra Banerjee Divakaruni, born in 1957 in Calcutta migrated to United States at the age of nineteen to earn a master's degree in English from Wright State University in Dayton, Ohio and she continued $\mathrm{PhD}$ programme in the University of California at Berkley. She began her writing career as a poet with the publication of The Reason for Nasturtiums (1990). Her first short story collection Arranged Marriage won American Book Award, PEN Josephine Miles Award and Bay Area Book Reviewers Award and paved way for her to become a high-profile writer in English literature. The Mistress of Spices, one of the bestselling novels of Divakaruni has been adapted into movie with the same title. Her major novels include The Mistress of Spices (1995), Sister of my Heart (1999), The Vine of Desire (2002), Queen of Dreams (2004), The Palace of Illusions (2008), One Amazing Thing (2010), Oleander Girl (2013), Before We Visit the Goddess (2016) and Brotherhood of the Conch Series: The Conch Bearer (2003), The Mirror of Fire and Dreaming (2005), Shadowland (2009). Her Short story collections include Arranged Marriage (1995), The Unknown Errors of Our Lives (2001) and The Lives of Strangers (2005). Chitra Banerjee Divakaruni's fictions were based on her personal experiences as an Indian immigrant in America. Most of her stories set in India and America excelling in themes like alienation, nostalgia, discrimination, feminism, modernism, east-west conflict, multiculturalism, identity crisis, human relationships, etc are analyzed and examined from various perspectives by the researchers and it is discussed in the paper to promote further scope of research.

The dissertation titled "Chitra Banerjee Divakaruni;s Novels1: A Thematic Study" by T. Chandra depicts power of women and their strong Indian rooted culture with reference to the heroines of Chitra Banerjee Divakaruni. The importance and greatness of Indian culture is revealed through the characters such as Draupadi, Tilo, Anju, Sudha, Rakhi and Mrs.Gupta. In relation to the title of the dissertation Chandra focused on various themes of Divakaruni's works that has interrelation with one another. Chandra discusses the major themes like feminism, multiculturalism, tradition and modernity, women's sufferings, human relationships, women relationship with man in all the novels of Divakaruni and finally magic realism in the novels The Conch Bearer, The Mirror of Fire and Dreaming and Shadowland. The article concludes with an idea that immigration ultimately ends in struggle between tradition and modernity, cultural crisis, search for self - identity and alienation.

The article entitled " $9 / 11$ and The Terror Fear in the Diasporic Community: The Recent Fiction of Chitra Divakaruni" written by Banani Chakraborty conveys the transformation in the position of diasporic community in United states after the Islamic terrorist attack on America in 9/11/2001 through the novels Queen of Dreams, One Amazing Thing and Oleander Girl. The attack not only shattered American citizens but also dropped its adverse effect on diasporic people due to the security norms by U.S. authority. Chakroborty, in Queen of Dreams, throws light on sufferings of second generation immigrants of America through the characters of the novel. Even though the second generation immigrants like Rakhi in Queen of Dreams, Korobi in Oleander Girl and Tariq and his family in One Amazing Thing accept the lifestyle and livelihood of America, their inner combat aspiring to connect their soul to their origin becomes even more crucial because of the strict security of the nation after the horrific attack is traced in the article.

'The article entitled "The Portrayal of Sister-friend in Chitra Banerjee Divakaruni's Sister of My Heart" by 
C.Bharathi traces out the feeling of sisterhood of a woman towards another woman. The novel is dominated by female characters of three mothers Gouri Ma, Nalini and Aunt Pishi and two young cousin sisters Anju and Sudha. Gauri Ma and Nalini support one another in bringing up their daughters in the fate of meager financial status. Bharathi interprets Divakaruni's depiction of friendship in sisterhood as both Anju and Sudha give importance to each other rather than their husbands in their life. Despite possessing jealousy, anger, antipathy in certain aspects towards each other, Sudha's forsaking her lover Ashoke to support Anju's wedding fantasy and Anju's struggle in bringing pathetic Sudha to America in order to build future even after knowing her husband's attraction towards Sudha's beauty, exhibits a strong bond between the sisters. As per review, Divakaruni displays the greater significance to relationships of woman and their potential to gratify existential motif of life.

Chitra Banerjee Divakaruni's The Vine of Desire: A Study of Immigrants's Cultural Dilemma's and Displacements by Ashok chaskar exposes the consequences of displacement. The Vine of Desire is sequel to Sister of My Heart in which the psychological change undergone by Sudha and Anju before and after migration is spotted. Ashok Chaskar's article discusses the reluctance of Divakaruni's character in continuing American life where Trideep's father and Sudha initially feel content with new American life but later adopt native land as their secured place. Sudha, brought up traditionally in a orthodox Bengali culture by three mothers tends to commit incest with Sunil after settling in Anju's house therefore deceiving her lovable sister Anju for whom once she had forsake her lover Ashoke. The article voices out the nature of American culture that claims the maxim "Live for Yourself" and fascinates Orient towards Occident, delineating the character Sudha.

"Self Revelation in Chitra Banerjee's The Mistress of Spices" by P.Valli Deivanai discloses Tilo's inner conflict of establishing self identity. Being Chitra Banerjee's first and the most popular novel, it received many critical appraisals for its uniqueness and the fused narrative technique of prose and poetry using the literary device of magical realism. The author of the research article figures out the protagonist Tilo's distinct identity from her birth to present. Being born with super natural power of fore saying she is named as Nayan Tara and when the pirates carries her away she is named Bhagyavathi and in the island she is named as Sarpakanya by the snakes and finally to become the mistress of spices she changed her name into Tilo meaning 'life giver'. The article also criticized the test posed on Tilo to choose between her identity of saving people from their adversity and her love towards Raven (American) like an ordinary woman.

Vasigaran in his doctoral work titled "Cross-Cultural Experiences of the Indian Womanhood through a Postcolonial Feminist Perspective: A Study on the Select Works of Chitra Banerjee Divakaruni” presents the Cross-Cultural experiences viewed by Divakaruni in her short stories such as Clothes, Silver Pavements, Golden Roofs, The Word Love from the short story collection Arranged Marriage and the novels The Mistress of Spices and Sister of My Heart. The researcher attempts to bring out women's misery in a patriarchal society stating "The ideal of the traditional, oppressed woman persisted in a culture permeated by religious images of virtuous goddesses devoted to their husband, the Hindu goddesses Sita and Savitri, serves as powerful cultural ideals for women" and the cultural clash encountered by South Asian immigrant women.

The research article "Reading Feminine Mysticism in Chitra Banerjee Divakaruni's Queen of Dreams" by Wenying Xu maps the story of Mrs. Gupta and Rakhi and reveals Divakaruni’s feminine mysticism. Divakaruni diminishes the power of patriarchal society by centering the extra ordinary super natural elements of women through the characters of Mrs. Gupta and her daughter Rakhi. The representation of female deity in the reading of Pre historic period in the novel evidences feminine mysticism. The Queen of Dreams has strong Hindu cultural background delineating the tradition of worshipping female goddesses which is contrast to the contemporary gender practices of India that degrades the possibility of women empowerment. "In other words, in Hindu culture "the Goddess pervades the world and everything in it.... Beyond and above, within and without, nothing exists or stirs in the cosmos that is not infused with the power of Goddess" (1). The researcher in the article exemplifies the 'Amaterasu', the sun Goddess of Japan and many Greek Goddesses parallel to the Hindu culture in the Prehistoric religious worship that promotes feminine mysticism in a patriarchal society. Divakaruni's feministic aspect is transparent in most of her works and in the Queen of Dreams, her abundance in incorporating super natural powers and potential to women characters indicates her contradiction to patriarchy.

The article named "Trauma and Repercussion in Golding's Lord of the Flies and Divakaruni's One Amazing Thing" written by Apara Tiwari aims to compare and contrast similarities and dissimilarities in both the works. The article presents the elementary nature of trauma and its effects in human behavioral science instancing two novels that has similarities in imposing characters to struggle for life. The children in Lord of the Flies enter into an isolate island during an air crash and struggle to signal for survival and in One Amazing Thing, the nine characters from different parts of world trapped in the basement of Visa office during earthquake seeking for the rescue team to approach them, come together and form basis for the comparison with the theme of trauma which is a common factor in both the novels. In One Amazing Thing the story of the nine characters revealed to one another at the trauma of life or death discloses the lives of loss, guilt, betrayal and misdeeds that bring salvation to all the characters. Divakaruni features the psychological change and the behavior at the known end of a life that influences in revelation of own self and the realization of self identity. 
Mahabharata, the great epic of India retold by Divakaruni in her novel The Palace of Illusions is advocated as a Postcolonial work of art by Ashalata Kulkarni in her article "Gender and Postcoloniality in Chitra Banerjee Divakaruni's The Palace of Illusions". The article connotes the fact of gender discrimination after British rule in India as explored by the famous psychologist Ashish Nandi "According to him earlier to British rule Indian gender roles were much more fluid and flexible but after the advent of British the imperial ideology of superiority of male and masculinity brought in the change of increase in the Kshatriya mode of masculinity". The saga is written from the perspective of Draupadi by Divakaruni. The Postcolonial aspects of gender, race and colonial impact were the chief discourse of the article in which Draupadi reflects gender bias. Racial discrimination is often spotted in the ancient period where the great legend like Dronacharya in Mahabarata rejects to educate Ekalavya as he belongs to the tribes.

Raminderpal Kaur in his article entitled "Female Quest for Identity by Chitra Banerjee Divakaruni, with special reference to Oleander Girl" voices Divakaruni's prominence of female characters and their individuality in her novel Oleander Girl. The novel centers the lead character Korobi Roy who deserves everything which an ordinary Indian girl longs for but struggles to find her identity after becoming aware of her migration to America in search of her father and past history.

The article “"The Old Rules Aren't Always right”: An Analysis of Four Short Stories by Chitra Banerjee Divakaruni" by Felicity Hand analyses the four short stories Affair, The Word Love, Doors, Ultrasound from the short story collection Arranged Marriage in multiple context. Divakaruni's appeal to gross Indian women through her writings is explored by the researcher in the article. Especially Divakaruni voices out for the Indian immigrant women who suffers for their self identity in a patriarchal society. Felicity Hand signifies the term 'Social Realism' which is rooted in the select four short stories of Divakaruni.

The article titled "Travelling across time: A Critical Analysis of The Mirror of Fire and Dreaming and Shadowland" by P.V.L. Sailaja and N. Ramakrishna deals with the notion of travelling across different time and space zones. The trilogy of the conch series revolves around the magical conch hidden in the mountain folds of Himalayas and the adventures behind the attainment of conch by Anand, the protagonist of the series of three novels and the evil characters ways out for the incorporation of dynamic theme by Divakaruni. Anand's time travel to past, future is described by Divakaruni by the means of fighting against the evil to locate all his missing friends and to protect the conch from corruption.

The review of the research articles and dissertations discusses various themes like alienation, feminism, patriarchy, cultural conflict, social realism, magical realism, self identity, incorporated by Chitra Banerjee Divakaruni as an eminent Indian diasporic writer. The research on the literary works of Divakaruni appeals her social contribution and the expression of personal experience to the world as the writer herself is an Indian born settled in America. The knowledge gap identified through the review is lack of criticism related to the men characters and societal provocation for the migration.

\section{References}

Chakraborty, Banani. 9/11 and the Terror Fear in the Diasporic Community: The Recent Fiction of Chitra Divakaruni, Fiction of Chitra Banerjee Divakaruni. 181-193.

Chaskar, Ashok. Chitra Banerjee Divakaruni's The Vine of Desire: A Study of Immigrant's Cultural Dilemmas and Displacements, Contemporary Discourse, 5; January 2014. 104-109.

$\mathrm{Xu}$, Wenying. Reading Feminine Mysticism in Chitra Banerjee Divakaruni's Queen of Dreams, South Asian Review 31. 1; November 2010. 186-207.

Kulkarni, Ashalata. (2012), Gender and Postcolooniality in Chitra Banerjee Divakaruni's The Palace of Illusions, The Quest 26 (1) pp. 186-207.

Deivanai, Valli P. (2011), Self Revelation in Chitra Banerjee's The Mistress of Spices, Voices of the Displaced: Indian Immigrant Writers in America. pp. 163-168.

Bharati, C. (2013), The Portrayal of Sister - friend in Chitra Banerjee Divakaruni's Sister of My Heart, The Quest, Vol. 27, No.2. pp. 61-70.

Kaur, Raminderpal. (2016), Female Quest for Identity by Chitra Banerjee Divakaruni, With special reference to Oleander Girl, Comtemporary, Vol.11 (13).

Hand, Felicity. (2004), “The Old Rules Aren’t always Right”: An Analysis of Four Short Stories by Chitra Banerjee Divakaruni, The Atlantic Literary Review, Vol.5, No.3. pp. 61-77.

Sailaja, P.V.L. and Ramakrishna N. (2011), Travelling across time: A Critical Analysis of The Mirror of Fire and Dreaming and Shadowland, The Quest. Pp. 20-26.

Tiwari, Apara. (2013), Trauma and Repercussion in Golding's Lord of the Flies and Divakaruni's One Amazing Thing, Literary Insight, Vol.4. pp. 114-118.

http://shodhganga.inflibnet.ac.in/handle/10603/133288

http:// shodhganga.inflibnet.ac.in/handle/10603/135383 